\title{
Description of a new synactinomyxon type from the River Sousa, Portugal
}

\author{
Cs. Székely ${ }^{1, *}$, J. C. Eiras ${ }^{2}$, E. Eszterbauer ${ }^{1}$ \\ ${ }^{1}$ Veterinary Medical Research Institute, Hungarian Academy of Sciences, Box 18, 1581 Budapest, Hungary \\ ${ }^{2}$ Departamento de Zoologia e Antropologia, and CIIMAR, Faculdade de Ciências, Universidade do Porto, 4099-002 Porto, Portugal
}

\begin{abstract}
Actinospore infection of oligochaetes collected from the mud of 2 freshwater biotopes in Portugal was studied. Using the 'cell-well plate method', a new synactinomyxon type was found in 2 specimens $(1.3 \%)$ of the examined Tubifex tubifex oligochaetes from the River Sousa north of Porto, Portugal. In Criodrilus lacuum and Dero digitata specimens collected from the same river, no actinosporeans were released during the 12 wk observation period. Infected oligochaetes were only found immediately post-collection, and no further actinosporean release was recorded in Tubifex specimens kept alive for several weeks. Actinospore infection showed high intensity in oligochaetes in both positive cases. No actinosporean stages of myxosporeans have as yet been described from Portugal. On the basis of spore morphology and $18 \mathrm{~S}$ rDNA sequence data, the synactinomyxon type presented in this paper differs from those already known and described in the literature.
\end{abstract}

KEY WORDS: Myxosporea $\cdot$ Actinospore $\cdot$ Tubifex tubifex $\cdot$ Oligochaete alternate host $\cdot$ 18S rDNA

\section{INTRODUCTION}

The first report on actinospores described these organisms as parasites related to myxosporeans (Štolc 1899); in the decades which followed, however, this parasite group was believed to represent an independent taxonomic entity. Research on actinosporeans became more intensive after Wolf \& Markiw (1984) proved that they corresponded to the intraoligochaete developmental stages of fish-parasitic myxosporeans (Kent et al. 2001). The relevant research has included surveys (Janiszewska 1957, Marques 1984), as well as studies on actinospore infection of oligochaetes in natural waters and fish farms in connection with the life cycle of myxosporeans (Kent et al. 2001). Several data are available on the myxosporean parasites of freshwater fishes from the Iberian Peninsula (Alvarez-Pellitero et al. 1979, 1982, Alvarez-Pellitero \& Gonzalez-Lanza 1985, Saraiva \& Molnár 1990, Cruz et al. 2000, Saraiva et al. 2000), but so far there is, to our knowledge, only 1 report on their possible alternative actinosporean forms (Székely et al. 2000).
In this paper we report on the finding and description of a new synactinomyxon type in an oligochaete host from a freshwater biotope in Portugal.

\section{MATERIALS AND METHODS}

Survey and morphological investigations. The survey was conducted in 2 biotopes: (1) In the Este River, $30 \mathrm{~km}$ north of Porto. In this biotope, there was an abundance principally of Barbus barbus, Leuciscus cephalus, Anguilla anguilla, Lepomis gibbosus and Chondrostoma polylepis. (2) In the Sousa River, $20 \mathrm{~km}$ northeast of Porto, where the Sousa River joins the Douro River. The most abundant fishes here were $B$. barbus, L. cephalus, A. anguilla and C. polylepis. All samplings were conducted in late May 2004 at a water temperature of 18 to $20^{\circ} \mathrm{C}$. To detect the intraoligochaete actinospore types, mud samples were collected and transported to the Animal Pathology laboratory at the Faculty of Sciences of Porto University. The oligochaetes were washed out from the mud on a dissection plate illuminated from below, and gently 
picked up using forceps. Large oligochaetes were separated from roots of aquatic weed at the sampling sites. After collection, the oligochaetes were placed individually into wells of cell-well plates according to Yokoyama et al. (1991). Starting from the subsequent day, the water layer above each oligochaete in each of the wells was examined daily, for $3 \mathrm{~d}$, for the presence of released actinospores. About half of the oligochaetes were then transported to Hungary in plastic tubes and monitored for actinospore release for a further $9 \mathrm{wk}$, while the rest of the specimens remained in Porto.

If the examination by stereomicroscope indicated spore release, the actinospores floating in, or adhering to, the wells of the cell-well plates were examined on a slide by light microscopy at high magnification. Microphotographs were then taken of the spores using a Zeiss Axiophot-type compound microscope attached to a computer, and the digital pictures were archived by Zeiss Axiovision software. Drawings were also made of the actinospores. The characteristic dimensions of actinospores were recorded according to the guidelines given by Lom et al. (1997). Measurements of 20 mature spores were averaged. The remaining released actinospores were fixed in $80 \%$ ethanol and transported to Hungary for further molecular biological studies. From both examined biotopes some of the representative (and infected) oligochaetes were fixed in $80 \%$ ethanol and identified by Dr. Tarmo Timm in Estonia, as described by Timm (1997).

For histological sections, infected oligochaetes were fixed in $10 \%$ neutral buffered formalin and embedded in Paraplast wax. After $5 \mu \mathrm{m}$ sections were made and stained with haematoxylin and eosin, photomicrographs of the sections were taken with an Olympus DP-10 digital camera mounted on an Olympus BH-2 microscope.

Molecular characterisation. DNA was extracted from actinospores fixed in $80 \%$ ethanol. Samples were centrifuged at $5000 \times g$ for $5 \mathrm{~min}$ and then air-dried. Spore pellets were re-suspended in $500 \mu \mathrm{l}$ lysis buffer $(100 \mathrm{mM} \mathrm{NaCl}, 10 \mathrm{mM}$ Tris, $10 \mathrm{mM}$ EDTA, 0.2\% SDS, and $0.4 \mathrm{mg} \mathrm{ml}^{-1}$ Proteinase $\mathrm{K}$ ) and incubated at $55^{\circ} \mathrm{C}$ for 3 to $4 \mathrm{~h}$. DNA was then purified using the Miniprep Express Matrix (BIO 101) (Eszterbauer 2004). The MX5-MX3 primer pair (Andree et al. 1999) was used for amplification. The total volume of the reaction was $50 \mu \mathrm{l}$, consisting of approx. $50 \mathrm{ng}$ DNA, $1 \times$ Taq PCR reaction buffer (MBI Fermentas), $1.25 \mathrm{mM} \mathrm{MgCl} 2,0.2 \mathrm{mM}$ dNTP mix (Sigma), 25 pmol of each primer and 2 units of Taq DNA Polymerase (MBI Fermentas). A Biometra T1 thermocycler was used for PCR. Amplification conditions were $95^{\circ} \mathrm{C}$ for $30 \mathrm{~s}$, $50^{\circ} \mathrm{C}$ for $30 \mathrm{~s}$ and $72^{\circ} \mathrm{C}$ for $80 \mathrm{~s}$ for 35 cycles, with an extension at $72^{\circ} \mathrm{C}$ for $7 \mathrm{~min}$. The PCR products were electrophoresed in $1.0 \%$ agarose gels (Sigma) in Tris Borate EDTA (TBE) buffer and then purified with Geneclean III Kit (Bio 101).

Purified PCR fragments of the sample were cloned into pGEM-T Vector System I (Promega) following the manufacturer's instructions. Positive clones were selected using the blue-white colour screening method. For confirmation, clones were sequenced with universal forward primer pUC/M13 (Promega). Thereafter, positive clones were sequenced in both strands with specific primers, as listed in Table 1, using the ABI BigDye Terminator v3.1 Cycle Sequencing Kit with an ABI 3100 Genetic Analyzer automated DNA sequencer (Applied Biosystems). For sequence assembling, the STADEN Sequence Analysis Package version 2001.0 (Staden 1996) was used. DNA sequence similarities were calculated with the Sequence Identity Matrix of the computer programme BioEdit.

\section{RESULTS}

\section{Survey and morphological investigations}

Oligochaetes from both sampling places were identified as the mature or juvenile forms of Criodrilus lacuum (120 individuals), Dero digitata (15 individuals) and Tubifex tubifex (150 individuals). Of the 285 oligochaetes examined, only $2 T$. tubifex specimens from the Sousa River proved to be infected by the new synactinomyxon type (Figs. $1 \& 2$ ). Both T. tubifex specimens released the same synactinomyxon type. All the spores were released during the first and second day after collection and placement of worms in the cell-well plates. No further actinospore release was found in other oligochaetes during the 9 wk observation period.

\section{Histology}

Early developmental stages and pansporocysts were located in the intestinal epithelium of the Tubifex

Table 1. Primers used for PCR and/or sequencing

\begin{tabular}{|lll|}
\hline Name & \multicolumn{1}{c|}{ Sequence } & \multicolumn{1}{c|}{ Source } \\
\hline MX5 & 5'- CTG CGG ACG GCT CAG TAA ATC AGT-3' & Andree et al. (1999) \\
MX3 & 5'- CCA GGA CAT CTT AGG GCA TCA CAG A-3' & Andree et al. (1999) \\
MB5r & 5'-ACC GCT CCT GTT AAT CAT CAC C-3' & Eszterbauer (2004) \\
MB3f & 5'-GAT GAT TAA CAG GAG CGG TTG G-3' & Eszterbauer (2004) \\
MC5 & 5'-CCT GAG AAA CGG CTA CCA CAT CCA-3' & Molnár et al. (2002) \\
MC3 & 5'-GAT TAG CCT GAC AGA TCA CTC CAC GA-3' & Molnár et al. (2002) \\
\hline
\end{tabular}




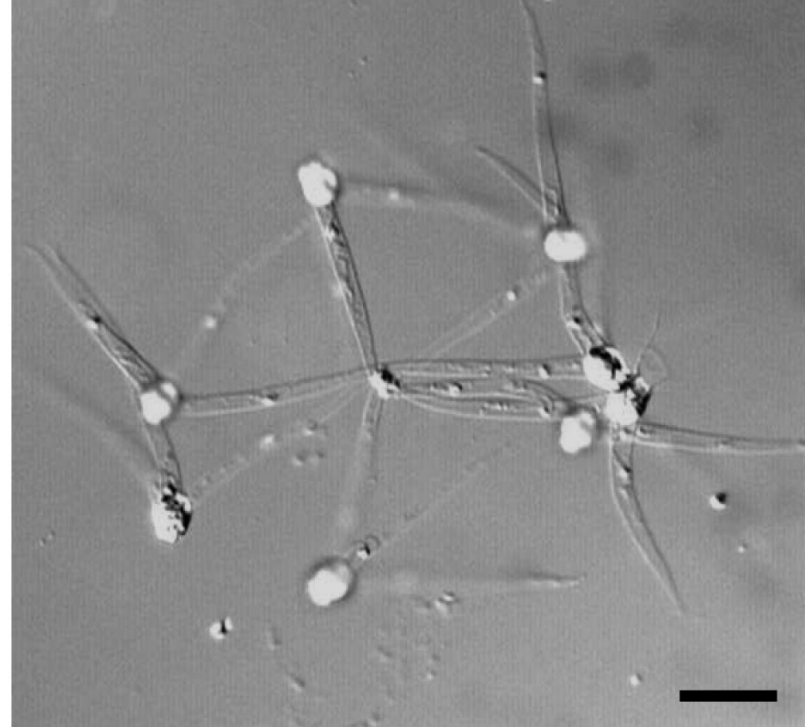

Fig. 1. Synactinomyxon spores forming an 8-spore unit released from a Tubifex tubifex specimen collected from the Sousa River. Scale bar $=50 \mu \mathrm{m}$

tubifex oligochaete, deforming and enlarging the normally monolayered epithelium (Fig. 3). At the infected part of the gut, almost all epithelial cells contained pansporocysts of different developmental stages. In some of the pansporocysts, the 8 developing synactinospore units were well visible. In the more developed pansporocysts, however, 4 actinospores were crosssectioned at the level of a sporoplasm, showing the number of secondary cells (Fig. 4).

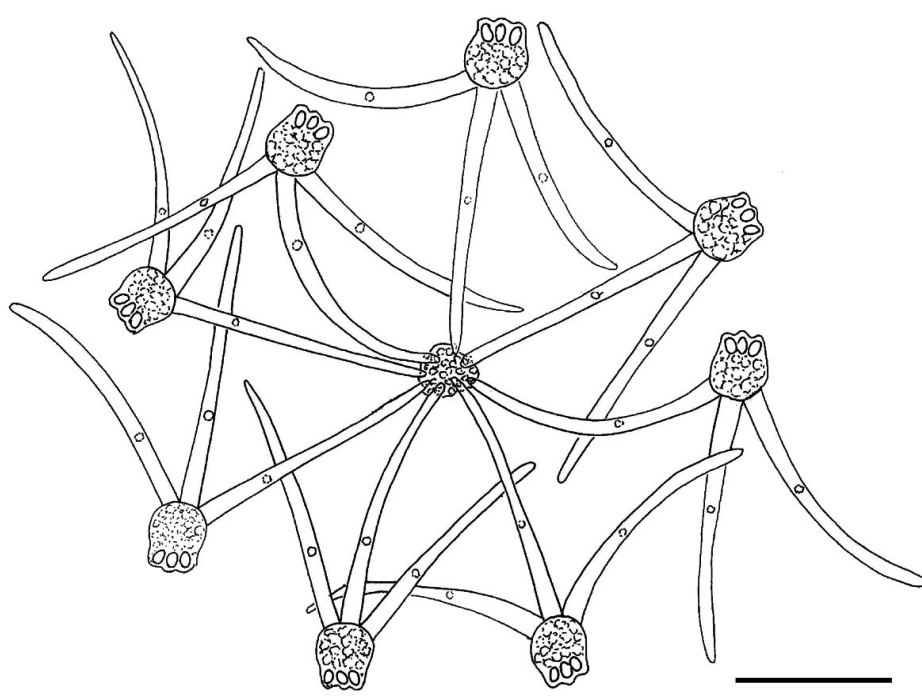

Fig. 2. Schematic drawing of the synactinomyxon type released by a Tubifex tubifex specimen from the Sousa River. Scale bar $=50 \mu \mathrm{m}$

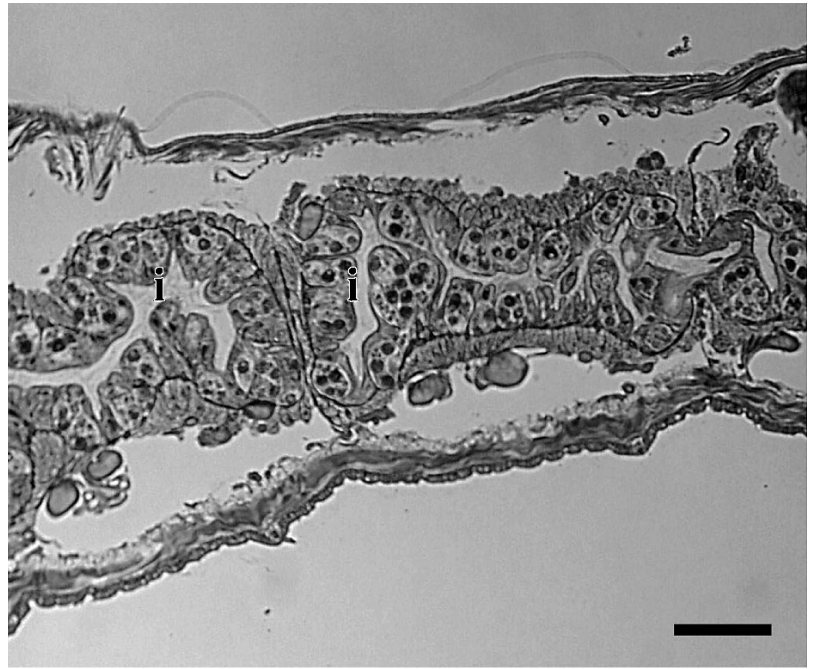

Fig. 3. Histological section of a Tubifex tubifex oligochaete. In each segment jammed cells of the proliferated epithelium containing synactinomyxon developmental stages are located around the intestinal lumen (i). Haematoxylin \& eosin (H \& E). Scale bar $=100 \mu \mathrm{m}$

\section{Description of the synactinomyxon type}

(Figs. 1, 2, 5, 6, 7, Table 2)

Eight spores, all of which were closely interconnected, joined together by the tip of one of their caudal processes. Three caudal processes, all equal in size, were considerably elongated. Spores were released from Tubifex tubifex. The spore body was $21 \mu \mathrm{m}$ long and $16 \mu \mathrm{m}$ wide. The number of secondary cells

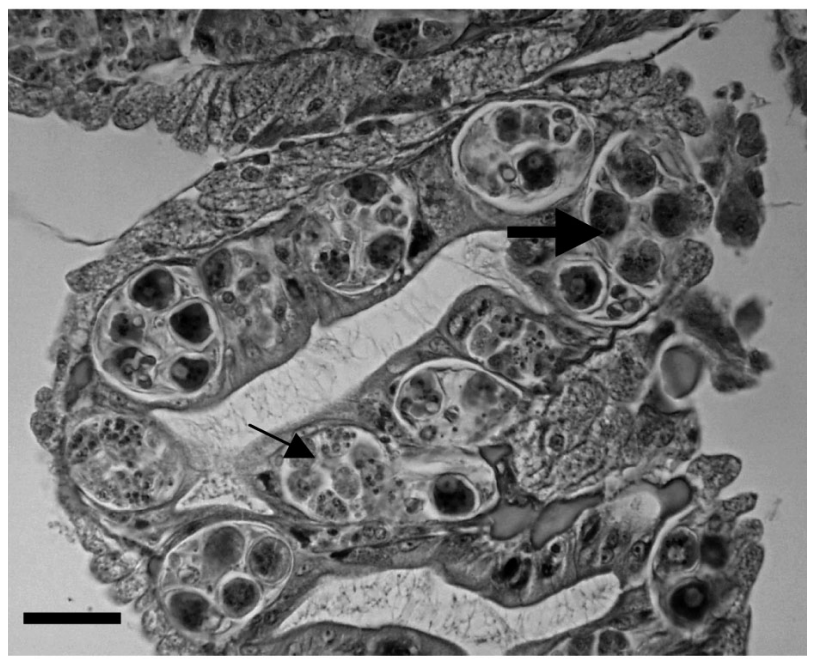

Fig. 4. Enlarged section of Fig. 3. Most of the epithelial cells are infected with pansporocysts of synactinomyxons. In younger pansporocysts (small arrow) 8 developing spores can be detected, in more developed pansporocysts (large arrow) only 4 spores located in one level and containing numbers of secondary cells are seen. $\mathrm{H} \& \mathrm{E}$. Scale bar $=25 \mu \mathrm{m}$ 


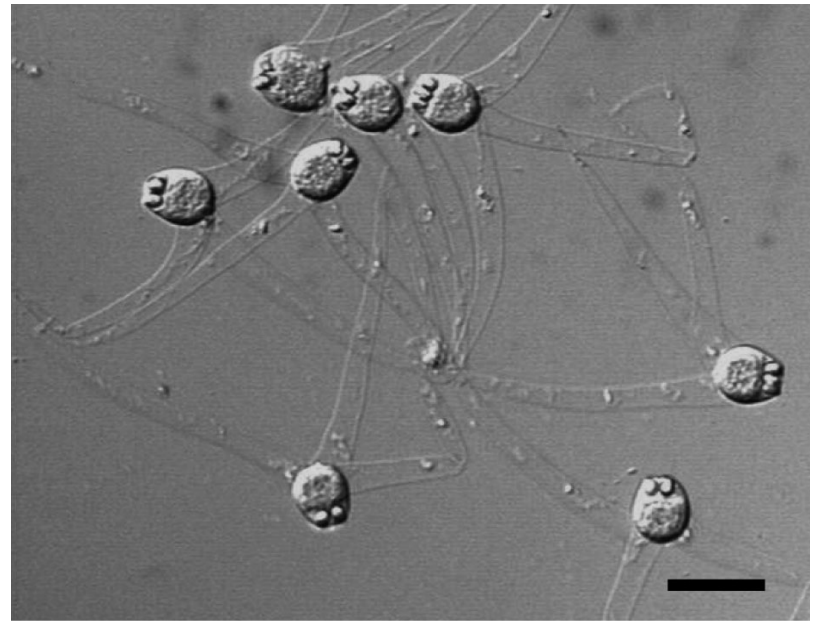

Fig. 5. Synactinomyxon spore-unit. Scale bar $=30 \mu \mathrm{m}$

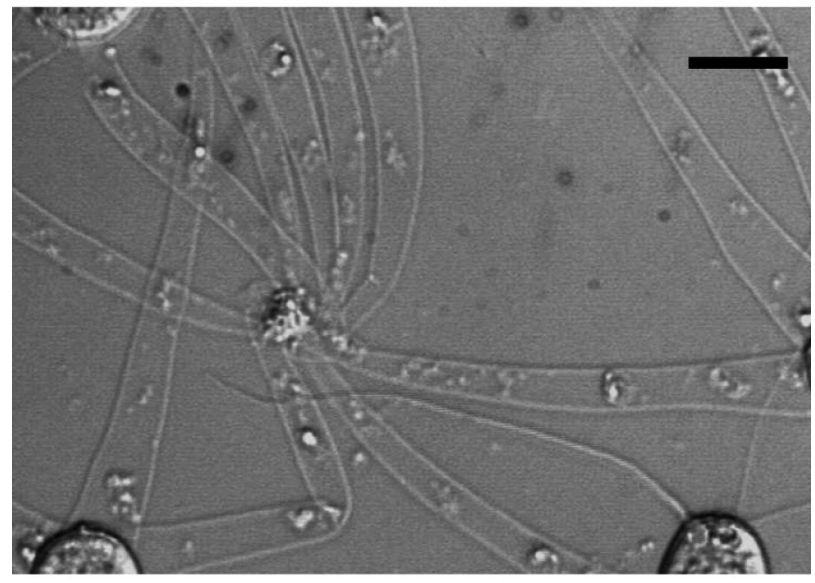

Fig. 6. View of the caudal processes showing the way in which the 8 processes are joined. Scale bar $=15 \mu \mathrm{m}$

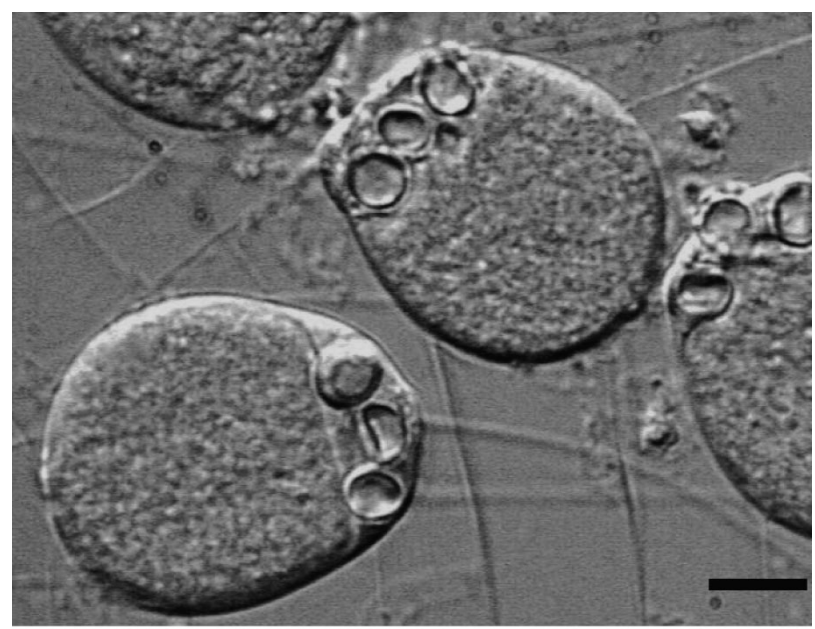

Fig. 7. Spore bodies of synactinomyxon spores. The 3 polar capsules and the extruded polar filaments are clearly visible. Scale bar $=5 \mu \mathrm{m}$ could not be determined precisely, but was at least 64 . Polar capsules with 3 to 4 coils of polar filament were sub-spherical and measured $5.6 \mu \mathrm{m} \times 4.8 \mu \mathrm{m}$. Caudal processes were the same size, i.e. $92 \mu \mathrm{m}$ in length.

Geographic source: Sousa River, Portugal.

Invertebrate host: Tubifex tubifex Müller, 1774.

Site of infection: actinospore developmental stages formed in the gut epithelium of the oligochaetes.

Differential diagnosis: Morphologically similar synactinospores were released from both infected Tubifex tubifex specimens. This synactinomyxon type resembled Synactinomyxon longicauda described by Marques \& Ormières (1982) and S. longicauda by McGeorge et al. (1997), although the length of the caudal processes differed considerably, being $80 \mu \mathrm{m}$ for the former synactinomyxon type and $64 \mu \mathrm{m}$ for the latter, in contrast to the $92 \mu \mathrm{m}$ we measured (Table 2).

\section{Molecular characterisation}

The specific primer pair MX5-MX3 successfully amplified approx. $1600 \mathrm{bp}$ fragments of the $18 \mathrm{~S}$ rDNA. Four of the 6 clones sequenced were $100 \%$ identical, while in 2 clones, 1 nucleotide difference was determined respectively, at different positions. A 1610 bp consensus DNA sequence was deposited in the GenBank under ccession number AY787784. This sequence was compared with myxosporean sequences available in the GenBank; Synactinomyxon longicauda (AJ582003) was determined to be the most similar, with $93.7 \%$ identical nucleotides, while the $18 \mathrm{~S}$ rDNA of Synactinomyxon sp. 'Type 1' (AJ582002) was $89.3 \%$ similar to that of synactinomyxon examined in the present study. The genetic similarity between Synactinomyxon sp. KAB-2001 (AF378354) and the one studied was fairly low $(72.6 \%)$. The $18 \mathrm{~S}$ rDNA sequences of myxosporean developmental stages available in the GenBank were found to be less than $90 \%$ similar to the synactinomyxon type examined, the most similar myxosporean being Myxidium lieberkuehni (X76638), with $75.6 \%$ identity over the 1653 bp long alignment.

\section{DISCUSSION}

After the pioneering work of Štolc (1899), several authors have reported on synactinomyxon types or species from natural waters (Janiszewska 1955, Marques 1984, Hamilton \& Canning 1987, McGeorge et al. 1997, Xiao \& Desser 1998, Özer et al. 2002) (Table 2). The synactinomyxon type described in this study differed substantially, in at least one of its dimensions, from the 8 synactinomyxon types recorded previously. 
Table 2. Comparison of synactinomyxon types described in the special literature. All measurements are in $\mu \mathrm{m}$. - : not applicable; nd = not determined; $\mathrm{D}=$ diameter; $\mathrm{L}=$ length; $\mathrm{W}=$ width

\begin{tabular}{|c|c|c|c|c|c|c|c|c|}
\hline \multirow[t]{2}{*}{$\begin{array}{l}\text { Type or species } \\
\text { (site of collection) }\end{array}$} & \multirow[t]{2}{*}{ Source } & \multirow[t]{2}{*}{ Spore body } & \multirow[t]{2}{*}{$\begin{array}{c}\text { Polar capsule } \\
\mathrm{L} \times \mathrm{W}\end{array}$} & \multicolumn{2}{|c|}{$\begin{array}{l}\text { Caudal processes } \\
\text { L (min.--max.) }\end{array}$} & \multirow{2}{*}{$\begin{array}{l}\text { No. of } \\
\text { secondary } \\
\text { cells }\end{array}$} & \multirow{2}{*}{$\begin{array}{l}\text { Coil no. of } \\
\text { polar capsule } \\
\text { filaments }\end{array}$} & \multirow{2}{*}{$\begin{array}{c}\text { Alternate } \\
\text { oligochaete } \\
\text { host }\end{array}$} \\
\hline & & & & & - & & & \\
\hline \multicolumn{9}{|l|}{$\begin{array}{l}\text { Synactinomyxon } \\
\text { tubificis }\end{array}$} \\
\hline $\begin{array}{l}\text { (1. Stvanice, former } \\
\text { Czechoslovakia; }\end{array}$ & 1. Štolc (1898) & & & & & & & Tubifex tubifex \\
\hline 2. Perpignan, France & 2. Marques (1984) & D: $12-15$ & $6 \times 3$ & 30 & - & 32 & nd & T. tubifex \\
\hline $\begin{array}{l}\text { 3. Cambrian } \\
\text { Fish Farm, British } \\
\text { Isles) }\end{array}$ & amilton \& Canning (1 & (987) & nd & nd & nd & nd & nd & T. tubifex \\
\hline $\begin{array}{l}\text { Synactinomyxon } \\
\text { longicauda } \\
\text { (Stream, Roussillon, } \\
\text { France) }\end{array}$ & $\begin{array}{c}\text { Marques \& } \\
\text { Ormières (1982) }\end{array}$ & D: $22-25$ & 7 & 80 & - & 16 & nd & T. tubifex \\
\hline $\begin{array}{l}\text { Synactinomyxon 'A' } \\
\text { (Salmon hatchery, }\end{array}$ & & $\begin{array}{l}\text { D: } 16.5 \\
(14-19)\end{array}$ & $5 \times 4$ & $\begin{array}{c}18 \\
(15-21)\end{array}$ & $\begin{array}{c}5.2 \\
(3-7)\end{array}$ & nd & nd & T. tubifex \\
\hline $\begin{array}{l}\text { Scotland) } \\
\text { Synactinomyxon 'B' } \\
\text { (= S. longicauda) } \\
\text { (Salmon hatchery, } \\
\text { Scotland) }\end{array}$ & $\begin{array}{c}\text { McGeorge et al. } \\
\text { (1997) }\end{array}$ & $\begin{array}{l}\text { L: } 21.3(20-23) \\
W: 18.3(16-20)\end{array}$ & $6 \times 4$ & $\begin{array}{c}64.4 \\
(55-80)\end{array}$ & - & nd & nd & $\begin{array}{l}\text { T. tubifex, } \\
\text { Lumbriculus } \\
\text { variegatus }\end{array}$ \\
\hline $\begin{array}{l}\text { Synactinomyxon } \\
\text { (Lake Sasajewun, Canada) }\end{array}$ & $\begin{array}{l}\text { Xiao \& Desser } \\
\text { a) }\end{array}$ & $\begin{array}{c}\text { L: } 31(28-35) \\
\text { W: } 17.5(16-18.5)\end{array}$ & $7.5 \times 4$ & $\begin{array}{c}138 \\
(125-150)\end{array}$ & - & $16-32$ & $3-4$ & T. tubifex \\
\hline $\begin{array}{l}\text { Synactinomyxon Type } 1 \\
\text { (Salmon farm, } \\
\text { Scotland) }\end{array}$ & & $\begin{array}{c}\text { D: } 17 \\
(14-19.2)\end{array}$ & $5 \times 4$ & $\begin{array}{c}18 \\
(15-21)\end{array}$ & $\begin{array}{c}5.3 \\
(3.2-7.4)\end{array}$ & 32 & nd & $\begin{array}{l}\text { T. tubifex, } \\
\text { L. variegatus }\end{array}$ \\
\hline $\begin{array}{l}\text { Synactinomyxon Type } 2 \\
\text { (Salmon farm, } \\
\text { Scotland) }\end{array}$ & Özer et al. (2002) & $\begin{array}{c}\text { D: } 16.8 \\
(16.4-17.2)\end{array}$ & $6.2 \times 5.4$ & $\begin{array}{c}33.6 \\
(31.2-37.4)\end{array}$ & $\begin{array}{c}5.4 \\
(3.8-7.8)\end{array}$ & 64 & nd & T. tubifex \\
\hline $\begin{array}{l}\text { Synactinomyxon Type } 3 \\
\text { (Salmon farm, } \\
\text { Scotland ) }\end{array}$ & & $\begin{array}{c}\text { L: } 25.6 \\
(21.8-26.5) \\
\mathrm{W}: 21.8(18.7-23.4)\end{array}$ & $5 \times 4$ & $\begin{array}{c}74 \\
(71.8-78)\end{array}$ & - & 16 & nd & $\begin{array}{l}\text { T. tubifex, } \\
\text { L. variegatus }\end{array}$ \\
\hline $\begin{array}{l}\text { Synactinomyxon } \\
\text { type } \\
\text { (River Souza, Portugal) }\end{array}$ & This study & $\begin{array}{l}\mathrm{L}: 21 \\
\mathrm{~W}: 16\end{array}$ & $\begin{array}{l}5.6 \\
4.5\end{array}$ & $\begin{array}{c}92 \\
(80-100)\end{array}$ & - & min. 64 & nd & T. tubifex \\
\hline
\end{tabular}

In addition to the morphological examinations, the results of molecular comparison also suggested that the synactinomyxon type examined in the present work had not been studied before. Although the morphology of actinospore units resembled the echinactinomyxon type, the actinospore examined was classified as synactinomyxon, because the 8 units joined at the tip of one of their caudal processes, which is a specific feature of the synactinomyxon collective group. Furthermore, the actinosporean types, which are morphologically and genetically the closest to the synactinomyxon type reported in this paper, did not possess fully identical dimensions: e.g. Synactinomyxon longicauda (Marques \& Ormieres 1982, McGeorge et al. 1997, Özer et al. 2002) differed in the length of the caudal processes. The data of the caudal processes of synactinomyxon types previously published in tabulated form by Özer et al. (2002) might contain an error: namely, S. tubificis and S. longicauda most likely did not have both a longer and a shorter process; the data given for length of short caudal processes probably corresponded to measurements for the diameter of caudal processes. Although among the hitherto clarified myxosporean life cycles reported in the literature there is no life cycle in which the intraoligochaete stage would be a synactinomyxon type, it is likely that the type found in the present study is an actinosporean stage of a fish or amphibian myxosporean parasite. Molecular biological examinations can neither confirm nor refute this theory as no $18 \mathrm{~S}$ 
rDNA sequences of myxosporean developmental stages available in the GenBank were similar to those of the synactinomyxon type described in the present study. Therefore, further transmission and molecular studies would be needed to identify the myxosporean counterpart of the synactinomyxon type examined.

This is the first report on an actinosporean stage of myxosporeans described from Portugal.

Acknowledgements. The authors thank Dr. Tarmo Timm (Limnological Station, Rannu, Estonia) for identification of the oligochaetes. The study was partially financed by grants from CIIMAR (Portugal) and from the Hungarian Scientific Research Fund (OTKA), projects no. T45891 and T42464. We also thank Mrs. Györgyi Patakiné Ostoros for the pencildrawings, and Mrs. Maria Helena Moreira for technical histological assistance.

\section{LITERATURE CITED}

Alvarez-Pellitero P, Gonzalez-Lanza C (1985) Studies on Myxobolus spp. of Barbus barbus bocagei from the river Esla (León, NW Spain). Angew Parasitol 26:3-12

Alvarez-Pellitero P, Pereira-Bueno J, Gonzalez-Lanza C (1979) Myxosporidios de Carassius carassius y Cyprinus carpio en el Rio Esla (Leon). Rev Iberica Parasitol 39: 611-623

Alvarez-Pellitero P, Pereira-Bueno J, Gonzalez-Lanza C (1982) On the presence of Chloromyxum truttae Leger, 1906 in Salmo trutta fario from Leon (Duero Basin, NW Spain). Bull Eur Assoc Fish Pathol 2:4-7

Andree KB, Székely C, Molnár K, Gresoviac SJ, Hedrick RP (1999) Relationships among members of the genus Myxobolus (Myxozoa: Bivalvidae) based on small subunit ribosomal DNA sequences. J Parasitol 85:68-74

Cruz C, Saraiva A, Ferreira S (2000) Preliminary observations on Myxobolus sp from cyprinid fish in Portugal. Bull Eur Assoc Fish Pathol 20:65-69

Eszterbauer E (2004) Genetic relationship among gill-infecting Myxobolus species (Myxosporea) of cyprinids: molecular evidence of importance of tissue-specificity. Dis Aquat Org 58:35-40

Hamilton AJ, Canning EU (1987) Studies on the proposed role of Tubifex tubifex (Muller) as an intermediate host in the life cycle of Myxosoma cerebralis (Hofer, 1903). J Fish Dis 10:145-151

Janiszewska J (1955) Actinomyxidia: morphology, ecology, history of investigations, systematics, development. Acta Parasitol Pol 2:405-443

Janiszewska J (1957) Actinomyxidia II: new systematics, sexual cycle, description of new genera and species. Zool Pol 8:3-34

Kent ML, Andree KB, Bartholomew JL, El-Matbouli M and 12 others (2001) Recent advances in our knowledge of the

Editorial responsibility: Wolfgang Körting,

Hannover, Germany
Myxozoa. J Eukaryot Microbiol 48:395-413

Lom J, McGeorge J, Feist SW, Morris D, Adams A (1997) Guidelines for the uniform characterisation of the actinosporean stages of parasites of the phylum Myxozoa. Dis Aquat Org 30:1-9

Marques A (1984) Contribution à la connaissance des Actinomyxidies: ultrastructure, cycle biologique, systematique. Thèse d'état, Université des Sciences et Techniques du Languedoc, Montpellier

Marques A, Ormières R (1982) La Spore des Actinomyxidies: Synactinomyxon longicauda n. sp., un nouveau type de groupement sporal et adaptations planctoniques: emission et structure du sporoplasme. J Protozool 29:195-202

McGeorge J, Sommerville C, Wootten R (1997) Studies of actinosporean myxozoan stages parasitic in oligochaetes from sediments of a hatchery where Atlantic salmon harbour Sphaerospora truttae infection. Dis Aquat Org 30:107-119

Molnár K, Eszterbauer E, Székely C, Dán Á, Harrach B (2002) Morphological and molecular biological studies on intramuscular Myxobolus spp. of cyprinid fish. J Fish Dis 25:643-652

Özer A, Wootten R, Shinn AP (2002) Survey of actinosporean types (Myxozoa) belonging to seven collective groups found in a freshwater salmon farm in Northern Scotland. Folia Parasitol 49:189-210

Saraiva A, Molnár K (1990) Myxobolus portucalensis n. sp. in the fins of European eel Anguilla anguilla (L.) in Portugal. Rev Iberica Parasitol 50:31-35

Saraiva A, Cruz C, Ferreira S (2000) Studies of Myxidium rhodei Leger, 1905 (Myxozoa : Myxosporea) on Chondrostoma polylepis from River Ave, North Portugal. Bull Eur Assoc Fish Pathol 20:106-110

Staden R (1996) The Staden sequence analysis package. Mol Biotechnol 5:233-241

Štolc A (1899) Actinomyxidies, nouveau groupe de Mesozoaires parent des Myxosporidies. Bull Int Acad Sci Boheme 22:1-12

Székely C, Sitja-Bobadilla A, Alvarez-Pellitero P (2000) First report on the occurrence of an actinosporean stage (Myxozoa) in oligochaetes from Spanish freshwaters. Acta Vet Hung 48:433-441

Timm T (1997) Freshwater Oligochaeta of some urban watercourses in the Russian Far East. Int Rev Ges Hydrobiol 82:437-467

Wolf K, Markiw ME (1984) Biology contravenes taxonomy in the Myxozoa: new discoveries show alternation of invertebrate and vertebrate hosts. Science 225:1449-1452

Xiao C, Desser SS (1998) Actinosporean stages of myxozoan parasites of oligochaetes from Lake Sasajewun, Algonquin Park, Ontario: new forms of echinactinomyxon, neoactinomyxum, aurantiactinomyxon, guyenotia, synactinomyxon and antonactinomyxon. J Parasitol 84: 1010-1019

Yokoyama H, Ogawa K, Wakabayashi H (1991) A new collection method of actinosporeans - a probable infective stage of myxosporeans to fishes - from tubificids and experimental infection of goldfish with the actinosporean, Raabeia sp. Fish Pathol 26:133-138

Submitted: October 29, 2004; Accepted: March 3, 2005

Proofs received from author(s): July 19, 2005 